\title{
Ocena standardu komunalnego budownictwa mieszkaniowego w małym mieście na przykładzie Twardogóry i Chocianowa
}

\author{
Milena Stettner
}

\author{
Katedra Urbanistyki i Procesów Osadniczych, Wydziat Architektury, Politechnika Wrocławska \\ e-mail:milena.stettner@pwr.edu.pl
}

\begin{abstract}
Streszczenie: Stan zabudowy mieszkaniowej wielorodzinnej zależy od polityki miasta w zakresie kształtowania zasobu komunalnego. Jest to zauważalne w porównaniu dostępności i standardu technicznego budynków. Autorka w niniejszym artykule analizuje kierunki zagospodarowania przestrzennego gminy i zestawia je ze szczegółową oceną stanu zabudowy mieszkaniowej wielorodzinnej w wybranych małych miastach do 10.000 mieszkańców: Chocianowie i Twardogórze (zlokalizowanych w woj. dolnośląskim) - miastach prezentujących strategię utrzymania dużego zasobu mieszkaniowego, a przez to kontroli nad kształtowaniem zabudowy. Artykuł prezentuje jeden z etapów realizowanego projektu badawczego - szczegółowa inwentaryzacja mienia komunalnego i analiza dokumentów planistycznych w 2 małych miastach o zbliżonej polityce mieszkaniowej, liczbie ludności, bez wpływu miasta metropolitalnego - który ma na celu próbę stworzenia optymalnego modelu zagospodarowania komunalnych terenów mieszkaniowych w śródmieściach małych miast do 10.000 mieszkańców w województwie dolnośląskim.
\end{abstract}

Słowa kluczowe: polityka mieszkaniowa, jakość życia, warunki mieszkaniowe, zasób komunalny.

\section{Wprowadzenie}

Zasady kształtowania polityki mieszkaniowej w małych miastach uzależnione są od celów przyjętych przez władze lokalne. Prezentują one różne strategie polityki mieszkaniowej, w jakich można zauważyć skrajne kierunki działań m.in. wzmożona sprzedaż lokali mieszkalnych w korzystnych warunkach finansowych na rzecz najemców (np. Międzybórz), sprzedaż starych lokali i budowa nowoczesnych osiedli mieszkań komunalnych (np. Świeradów-Zdrój) lub zatrzymanie zasobu mieszkaniowego z przyjętą polityką kontroli nad kształtowaniem zagospodarowania miasta (np. Twardogóra). W tym miejscu pojawia się problem badawczy - czy jednorazowy zastrzyk gotówki ze sprzedaży mieszkań komunalnych jest lepszy dla miasta, czy miesięczne korzyści płynące z wynajmu - który autorka próbuje rozwiązać w swoim projekcie badawczym dotyczącym próby stworzenia optymalnego modelu zagospodarowania komunalnych terenów mieszkaniowych w małych miastach do 10.000 mieszkańców na przykładzie województwa dolnośląskiego.

W niniejszym artykule zostanie przedstawiony jeden z etapów projektu badawczego - na przykładzie dwóch małych miast, prezentujących politykę mieszkaniową polegającą na utrzymaniu gminnego zasobu mieszkaniowego - jakim jest szczegółowa inwentaryzacja i ocena komunalnych terenów zabudowy mieszkaniowej. Chocianów i Twardogóra to miasta posiadające ok. 7000-8000 mieszkańców, oddalone od siebie ok. 170 km, bez wpływu miasta metropolitalnego i funkcji sypialni, posiadające centralnie położony Rynek Starego Miasta 
oraz zabudowę mieszkaniową wielorodzinną, głównie kamienicową, powstałą na początku XX wieku. Wraz z 10 pozostałymi, biorącymi udział w badaniu, zostały wyłonione spośród wszystkich 54 małych miast do 10.000 mieszkańców w województwie dolnośląskim, jako te w najlepszej kondycji społeczno-gospodarczo-ekonomicznej. Głównym elementem szczegółowej inwentaryzacji terenu była ocena stanu komunalnej zabudowy mieszkaniowej wg przyjętego kryterium (tabela poniżej). Oprócz stanu technicznego zabudowy, analizą objęto sposób zagospodarowania i wykorzystania podwórka. Dodatkowym elementem analizy była także odległość do centrum i wpis do rejestru zabytków (ze względu na trudność i koszty przyszłych prac budowlanych). Większość budynków pochodzi z początku XX wieku, widnieje w rejestrze zabytków, a jego stan techniczny zazwyczaj wymaga gruntownej modernizacji i dostosowania do dzisiejszych potrzeb mieszkańców.

Na podstawie wykazów gminnego zasobu zabudowy mieszkaniowej wielorodzinnej otrzymanych od samorządów gminnych zaznaczono na mapie lokalizację gminnych budynków mieszkaniowych. Kolejnym etapem analizy była szczegółowa inwentaryzacja fotograficzna i ocena budynków oraz terenów wokół obiektów. Według niżej zaprezentowanego kryterium, ocenie podlegały:

- stan techniczny budynku

\begin{tabular}{ll}
\hline bardzo dobry & $\begin{array}{l}\text { wykonany remont budynku: } \\
\text { ocieplenie, elewacja, dach, wymienione okna i drzwi }\end{array}$ \\
\hline dobry & elewacja i dach - stary, ale w dobrym stanie, wymienione okna i drzwi \\
\hline zły & wszystko nadające się do wymiany \\
\hline bardzo dobry & $\begin{array}{l}\text { duże, zagospodarowane podwórko, dostęp do zieleni, parkingu, } \\
\text { komórki lokatorskiej }\end{array}$ \\
\hline dobry & $\begin{array}{l}\text { niewielkie, zagospodarowane podwórko lub duże, ale wymagające } \\
\text { zagospodarowania, tzn. zielen, parking }\end{array}$ \\
\hline zły & podwórko wykorzystywane jedynie pod nielegalny parking \\
\hline
\end{tabular}

\section{Polityka mieszkaniowa $w$ gminie}

Polityka rozumiana jest na wiele sposobów, jednak zawsze towarzyszą jej określone cele stawiane przez osoby odpowiedzialne za ich realizację i ukierunkowane w danej dziedzinie. Polityka jest jednym z podstawowych elementów życia społecznego i obowiązkowo obejmuje 3 fazy: ,1) określenie celów, czyli sformułowanie odpowiedzi na pytanie $<<$ po co działać $>>$ lub $<<$ co chcemy osiągnąć $>>$; 2) opracowanie i przyjęcie celów polityki, powiązanej z określeniem sekwencji działań pozwalających osiągnąć założone cele; 3) sterowanie rozwojem, czyli podejmowanie kluczowych działań, których skutkiem jest realizacja opracowanych w pierwszej fazie celów" [1]. W niniejszym artykule mamy do czynienia z polityką mieszkaniową w małych miastach do 10.000 mieszkańców w województwie dolnośląskim, a jej głównym elementem jest gospodarowanie gminnym zasobem mieszkaniowym. Zgodnie $\mathrm{z}$ definicją Ustawy z dnia 21 czerwca 2001 r. o ochronie praw lokatorów, mieszkaniowym zasobie gminy i o zmianie Kodeksu cywilnego „mieszkaniowy zasób gminy - należy rozumieć jako lokale stanowiące własność gminy albo gminnych osób prawnych lub spółek 
handlowych utworzonych z udziałem gminy, z wyjątkiem towarzystw budownictwa społecznego, a także lokale pozostające w posiadaniu samoistnym tych podmiotów" [2].

Polityka mieszkaniowa obejmuje działania zmierzające do zapewnienia proporcjonalnej bazy mieszkaniowej w stosunku do panujących potrzeb w danej jednostce miejskiej oraz utrzymania jej na określonym poziomie: stan techniczny, dostępność do infrastruktury technicznej, zagospodarowanie terenu wokół obiektu, odpowiednia powierzchnia dla konkretnej rodziny i rozsądny czynsz najmu. Główną rolę w kreowaniu polityki mieszkaniowej pełnią samorządy gminne, które mają zapewnić lokale mieszkalne obywatelom, w szczególności rodzinom o najniższych dochodach. Niedobory ilościowe i jakościowe to główny problem samorządów, jak wspomniano we wprowadzeniu, opracowywane małe miasta prezentują trzy typy prowadzenia polityki mieszkaniowej, jednak każdy z nich wymaga udoskonalenia. W dobie kryzysu sytuacji mieszkaniowej w Polsce, „racjonalność wykorzystania i efektywności gospodarowania istniejącymi zasobami mieszkaniowymi gmin nabiera szczególnie istotnego znaczenia" [3] dla stawiania celów w obrębie gospodarowania budżetem gmin i podejmowania decyzji na zatrzymaniu starego zasobu mieszkaniowego, bądź pozbywania się go w korzystnych dla najemców warunkach finansowych.

Gospodarka nieruchomościami w gminie opiera się na dwóch grupach instrumentów, dzięki którym władze samorządowe definiują swoje cele i dążą do ich realizacji. W stosunku do majątku komunalnego gmina może aktywnie zarządzać majątkiem, sprzedając i wynajmując lokale, przekazywać nieruchomości w trwały zarząd, stosować opłaty adiacenckie oraz przyznawać bonifikaty w przypadku ich zbycia. Druga grupa instrumentów to działania pośrednie w postaci tworzenia opracowań planistycznych, inwestowania w grunty i nową zabudowę mieszkaniową, a także kształtowanie sfery popytu i podaży na rynku nieruchomości [4].

\section{Instrument ksztaltowania przestrzeni - Studium Uwarunkowań i Kierunków Zagospodarowania Przestrzennego}

Kształtowanie przestrzeni w miastach wg ustawy o planowaniu i zagospodarowaniu przestrzennym [5] regulowane jest przez studium uwarunkowań i kierunków zagospodarowania przestrzennego gminy oraz zgodny z nim akt prawa miejscowego - miejscowy plan zagospodarowania przestrzennego. Ważnym aspektem studium są kierunki przekształceń z przewidywaną prognozą kształtowania zagospodarowania gminy w różnych aspektach: funkcjonalnym, społeczno-gospodarczym, środowiskowym, kulturowym i kompozycyjno-estetycznym, w perspektywie następnych kilkunastu lat. Ład przestrzenny - powoływany w ustawie o planowaniu i zagospodarowaniu przestrzennym - łączy w sobie wszystkie wyżej wymienione aspekty, zapewniając harmonię w zagospodarowaniu miasta/gminy. Opracowanie, na podstawie którego tworzy się miejscowe plany zagospodarowania przestrzennego, tworzone jest dla całej gminy. Nie stanowi ono aktu prawa miejscowego, jednak jest nieodłącznym elementem do późniejszego wyznaczenia wskaźników planowanej zabudowy. Nieracjonalnie prowadzona polityka przestrzenna może prowadzić do zachwiania ładu, a przez to nadmiernej intensywności zabudowy bez zapewnienia terenów zielonych, rekreacyjnych i wystarczającej infrastruktury technicznej [4].

Małe miasta do 10.000 mieszkańców to najmniejsze jednostki miejskie, ale i najczęściej występujące w Polsce (701 małych miast na 930 wszystkich miast), dlatego kreowanie ich przestrzeni jest niebywale ważne. W zaprezentowanych 2 miasteczkach, główne kierunki polityki kształtowania przestrzeni w zakresie zabudowy mieszkaniowej wielorodzinnej 
w całym Chocianowie, to: zachowanie $25 \%$ powierzchni biologicznie czynnej terenu, wysokość budynków nieprzekraczająca $18 \mathrm{~m}$, zapewnienie minimum 1 miejsca parkingowego na mieszkanie i wskaźnik intensywności zabudowy nieprzekraczający 2,5 [6]; natomiast w Twardogórze: wysokość do $15 \mathrm{~m}$, dopuszczone elementy towarzyszące w postaci usług, garaży, budynków gospodarczych i konieczność przeznaczenia części terenu pod zieleń [7]. Studium Twardogóry ma formę bardzo ogólną, nie definiuje konkretnych wskaźników kształtowania zabudowy, jak w przypadku Chocianowa, które miejscami jest zbliżone do mpzp ${ }^{1}$, ze względu na szczegółowe wskaźniki kształtowania zabudowy, m.in. określenie intensywności zabudowy, powierzchni terenu biologicznie czynnego, wysokości zabudowy. Zapis o przeznaczeniu części nieruchomości gruntowej na zieleń przydomową, bez zdefiniowania procentowego udziału działki, może prowadzić do pozostawiania jedynie „skrawka” terenu, którego w żaden sposób nie uda się wykorzystać na cele rekreacyjne. Plan miejscowy powinien określać szczegółowe wytyczne zagospodarowania przestrzeni. Jednak z uwagi na niewielkie pokrycie małych miast planami miejscowymi - ze względu na wysokie koszty wykonania mpzp [8] - wyznaczenie przynajmniej podstawowych wskaźników kształtowania polityki przestrzennej w suikzp² ${ }^{2}$ może przyczynić się do wydawania przez jednostki samorządu terytorialnego rozsądnych decyzji o warunkach zabudowy.

\section{Standard zabudowy mieszkaniowej wielorodzinnej w małym mieście}

\subsection{Chocianów - „miasto Rynek”}

Chocianów to małe miasto w powiecie polkowickim, w województwie dolnośląskim, położone ok. $100 \mathrm{~km}$ od Wrocławia, otoczone Przemkowskim Parkiem Krajobrazowym, z centralnie umieszczonym Rynkiem Starego Miasta, zabytkową zabudową kamienicową, kościołem w centrum i parkiem pałacowym w sąsiedztwie (Rys. 2). Miasto o powierzchni 7 km², zamieszkuje ok. 8000 mieszkańców. Rynek Starego Miasta w Chocianowie to reprezentacyjne miejsce miasteczka, z uporządkowaną zabudową mieszkaniową wielorodzinną, prezentujące odnowioną nawierzchnię i elewacje budynków, zadbaną roślinnością i szeregiem drobnych usług w parterach kamienic, które tętnią życiem „w sobotę rano” (Rys. 1).

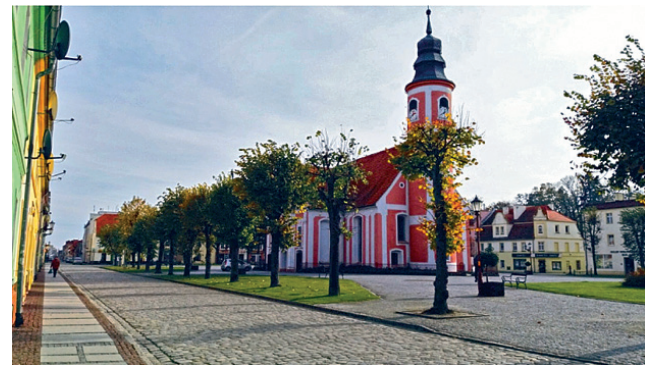

Rys. 1. Rynek w Chocianowie

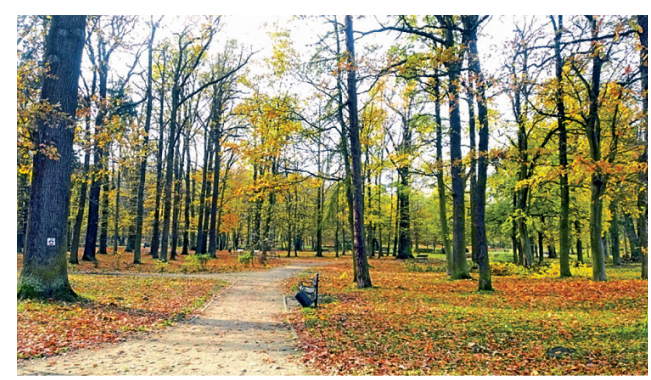

Rys. 2. Park pałacowy w Chocianowie

\footnotetext{
Miejscowy plan zagospodarowania przestrzennego.

2 Studium uwarunkowań i kierunków zagospodarowania przestrzennego.
} 
Autorka bada małe miasta od 2014 r., w których zaobserwowała wiele miejsc centralnych w miasteczkach, w postaci rynków, głównych ulic, czy placów. Jednak Rynek w Chocianowie to niemal ,idealne miejsce małego miasta”. Zazwyczaj drobne usługi, które powinny być charakterystycznym elementem miasteczek, wypierane są przez supermarkety i dyskonty budowane na obrzeżach, a funkcja usługowa miejsc centralnych zanika, prowadząc do pustoszenia „serca miasteczka” i utraty dominacji w mieście [9]. W Chocianowie jest ona utrzymana w należytej kondycji i może stanowić dobrą praktykę kształtowania przestrzeni publicznych w małych miastach.

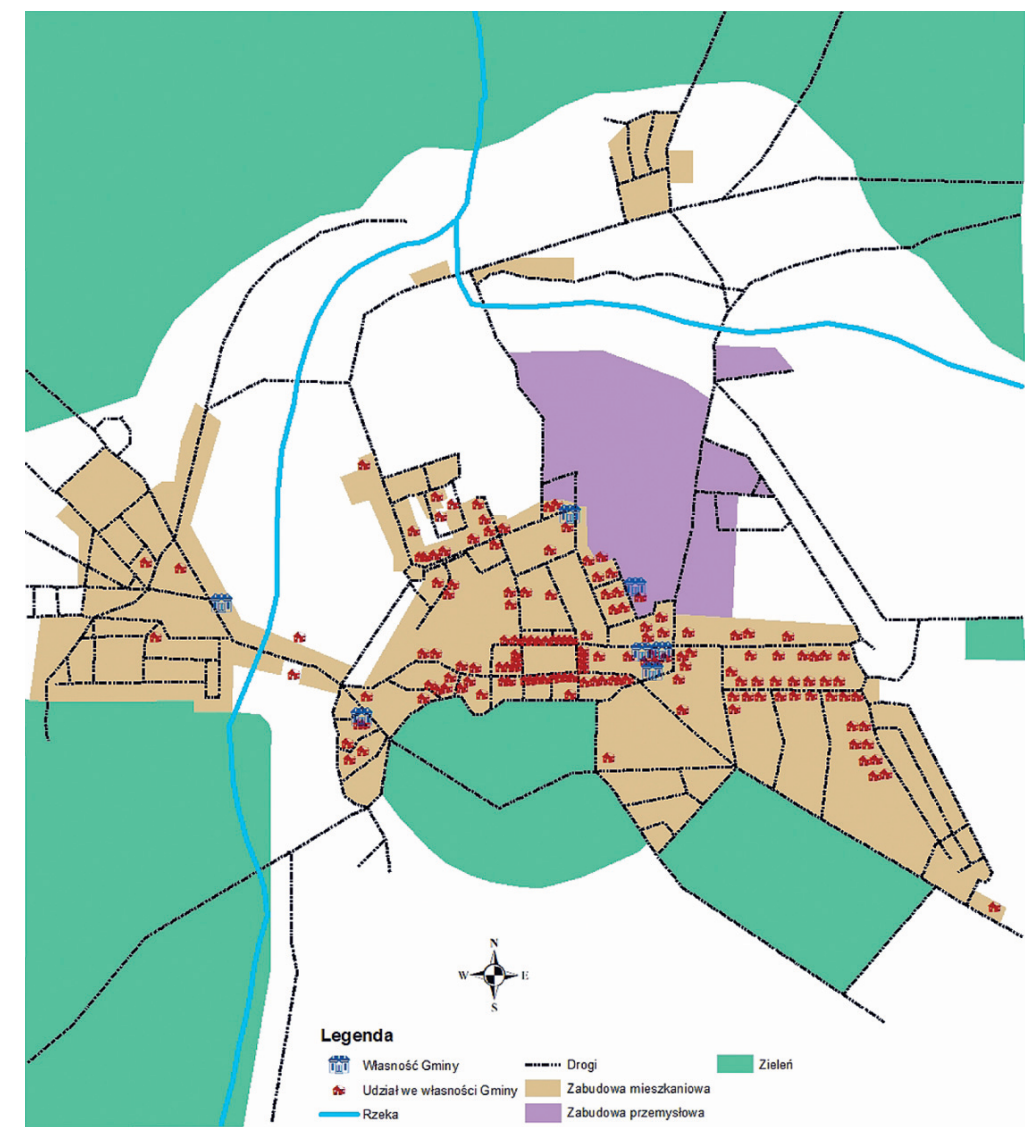

Rys. 3. Struktura funkcjonalno-przestrzenna miasta Chocianów

Zabudowa mieszkaniowa wielorodzinna w Chocianowie to w przeważającej części kamienice 3-kondygnacyjne, powstałe na początku XX wieku. Gmina Chocianów posiada w mieście 7 budynków na własność (Tab. 1) oraz udział w 146 (Tab. 2). Łącznie daje to 305 lokali mieszkalnych. Budynki komunalne prezentują różny poziom stanu technicznego oraz zagospodarowania terenu wokół nieruchomości. Mieszkania komunalne znajdują się głównie w centrum miasta. Największa odległość to ok. 1 km od Rynku (Rys. 3). Północ miasta to duży teren przemysłowy z aktywnie działającymi fabrykami, m.in. Chofum S.A., co napędza gospodarkę miasteczka, wyznaczając jej główną funkcję i dopełniając aktywnie działające usługi w centrum. 
Tabela 1. Własności miasta Chocianów - zabudowa mieszkaniowa wielorodzinna

\begin{tabular}{llccccc}
\hline lp. & $\begin{array}{c}\text { adres } \\
\text { nieruchomości }\end{array}$ & zabytek & $\begin{array}{c}\text { droga } \\
\text { dojazdowa }\end{array}$ & $\begin{array}{c}\text { odległość } \\
\text { do centrum }\end{array}$ & $\begin{array}{c}\text { stan } \\
\text { techniczny }\end{array}$ & $\begin{array}{c}\text { sposób zagospodaro- } \\
\text { wania i wykorzystania } \\
\text { podwórka }\end{array}$ \\
\hline 1 & $\begin{array}{l}\text { ul. Bohaterów Wojska } \\
\text { Polskiego 46 }\end{array}$ & tak & asfalt & $850 \mathrm{~m}$ & bardzo dobry & dobry \\
\hline 2 & ul. Dominalna 6 & nie & asfalt & $500 \mathrm{~m}$ & zły & dobry \\
\hline 3 & ul. Fabryczna 17 & tak & asfalt & $500 \mathrm{~m}$ & dobry & zły \\
\hline 4 & ul. Głogowska 3 & nie & asfalt & $400 \mathrm{~m}$ & bardzo dobry & zły \\
\hline 5 & ul. Kolejowa 16 & nie & asfalt & $350 \mathrm{~m}$ & bardzo dobry & zły \\
\hline 6 & ul. Kolejowa 20 & tak & asfalt & $400 \mathrm{~m}$ & bardzo dobry & dobry \\
\hline 7 & ul. Zaułek Fabryczny 1 & tak & gruntowa & $350 \mathrm{~m}$ & zły & zły \\
\hline
\end{tabular}

Tabela 2. Udział we własności miasta Chocianów - zabudowa mieszkaniowa wielorodzinna

\begin{tabular}{|c|c|c|}
\hline lp. & adres $n$ & uchomości \\
\hline 1 & ul. Apteczna 1 & ul. Piotrowska 15 \\
\hline 2 & $\begin{array}{l}\text { ul. Bohaterów Wojska Polskiego } \\
6,8,11,24,27,32,46\end{array}$ & ul. Pocztowa 3, 5 \\
\hline 3 & ul. Dominalna 10, 10a, 12, 14, 16 & ul. Ratuszowa $1,4,5,7$ \\
\hline 4 & ul. Fabryczna 2, 2a, 4, 4a, 6, 6a, 8, 8a, 15 & $\begin{array}{l}\text { ul. Rotmistrza Witolda Pileckiego 2, 4, 7, 12, } \\
\text { 14, 14a, 14b, 15, 16, 17, 19, 22, 24, 26, 26a }\end{array}$ \\
\hline 5 & ul. Głogowska 4, 6, 7, 9, 10, 14 & ul. Sportowa 1a, $1 \mathrm{~b}$ \\
\hline 6 & ul. Kasztanowa 1 & ul. Trzebnicka 1, 11 \\
\hline 7 & $\begin{array}{l}\text { ul. Kolejowa 1, 2, 10, 11, 15, 18, 19, 22, } \\
23,25,34,39,42,45,47,48,51,52,53\end{array}$ & ul. 3-go Maja 1 \\
\hline 8 & ul. Kolonialna 1, 15 & ul. Tylna 1 \\
\hline 9 & $\begin{array}{l}\text { ul. Kościuszki 2, 3, 4, 5, 6, 11, 12, 13, 16, } \\
18,20,22\end{array}$ & ul. Wesoła 4, 4a, 6, 6a, 8, 8a, 10, 10a \\
\hline 10 & ul. Kwiatowa 1 & ul. Wspólna 1 \\
\hline 11 & $\begin{array}{l}\text { ul. Lipowa 2, 3, 4, 5, 6, 7, 8, 9, 10, 11, 12, } \\
13,14,15,16,18\end{array}$ & ul. Zamkowa 1, 2 \\
\hline 12 & ul. Ogrodowa 3 & ul. Zaułek Fabryczny 3 \\
\hline 13 & $\begin{array}{l}\text { pl. Wolności } 1,2,3,4,5,6,7,8,9,10,11 \text {, } \\
12,13,14,15,16,17,18,19,20,21,25\end{array}$ & ul. Żeromskiego 2, 4, 5, 10, 10a, 12 \\
\hline
\end{tabular}

Żaden z analizowanych budynków w Chocianowie nie posiada placu zabaw, większość z nich także nie ma zieleni przydomowej, a na średniej wielkości podwórkach, można spotkać jedynie miejsce do parkowania. W części budynków została odnowiona elewacja (ul. Głogowska 3, Kolejowa 16, 20, Bohaterów Wojska Polskiego 46) (Rys. 4, 6) i głównie 
przy tych obiektach podwórko jest zagospodarowane (Rys. 5). Budynki w najgorszym stanie technicznym, ,straszą" nie tylko formą zabudowy (Rys. 7, 8), ale również zagospodarowaniem terenu wokół nieruchomości (Rys. 9).

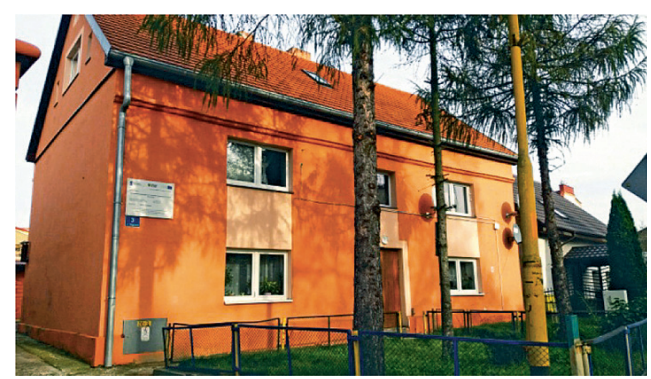

Rys. 4. ul. Głogowska 3, front budynku

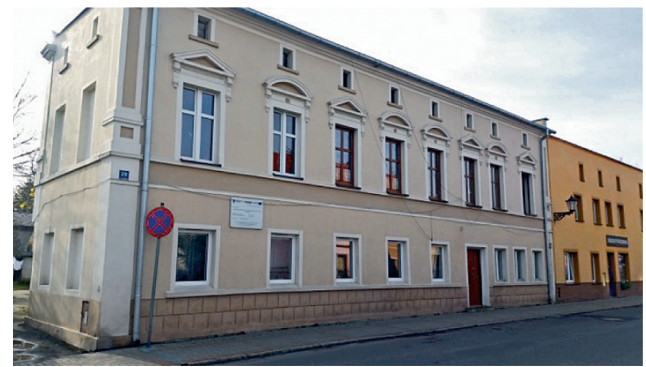

Rys. 6. ul. Kolejowa 20, front budynku

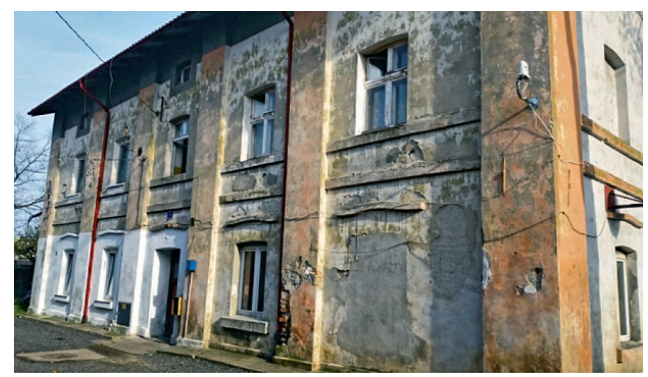

Rys. 8. ul. Zaułek Fabryczny 1, front budynku

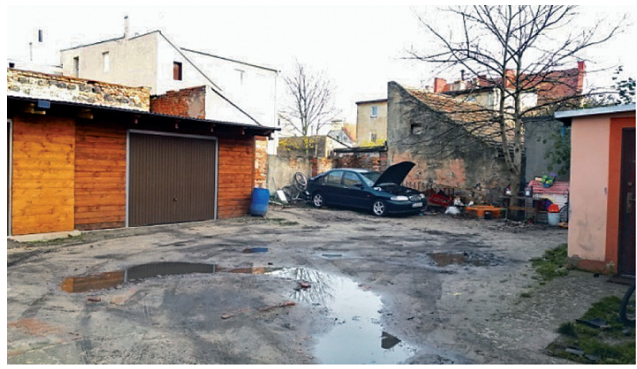

Rys. 5. ul. Głogowska 3, podwórko

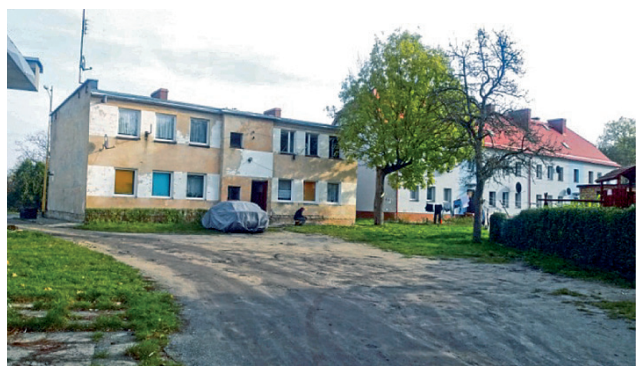

Rys. 7. ul. Dominalna 6, podwórko

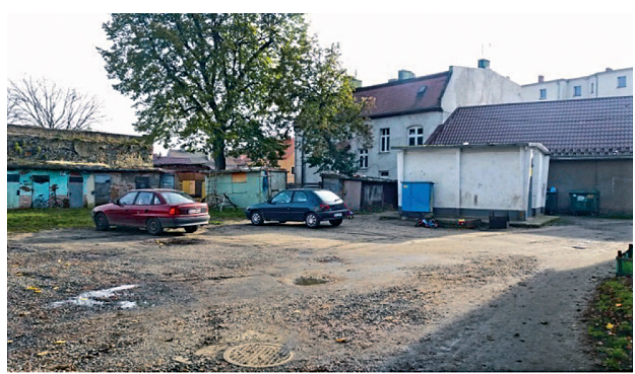

Rys. 9. ul. Zaułek Fabryczny 1, podwórko

\subsection{Twardogóra - „miasto zabudowy komunalnej”}

Twardogóra to miasto liczące ok. 7000 mieszkańców, położone na północny-wschód od Wrocławia, w odległości ok. $50 \mathrm{~km}$, o powierzchni ponad $8 \mathrm{~km}^{2}$, z centralnie położonym Rynkiem Starego Miasta i z Ratuszem na środku (Rys. 10) oraz sąsiadującym parkiem otoczonym również zabudową mieszkaniową wielorodzinną w postaci kamienic i kościołem w centrum. Oprócz niewielkiego parku w sąsiedztwie rynku, w miasteczku znajduje się deptak z zielenią urządzoną wzdłuż rzeki Skoryni, sfinansowany ze środków UE, prowadzący m.in. do basenu i lodowiska miejskiego, przy zabytkowym szachulcowym kościele Św. Trójcy i MB (Rys. 11). 


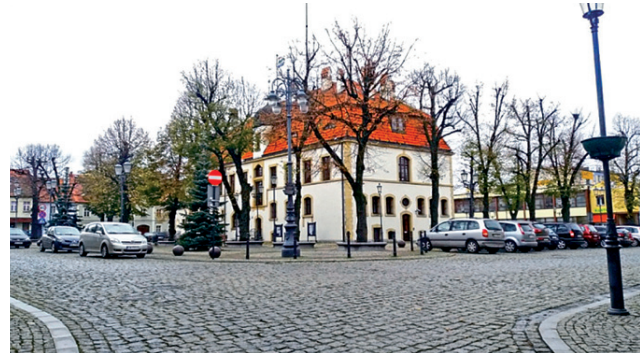

Rys. 10. Rynek w Twardogórze

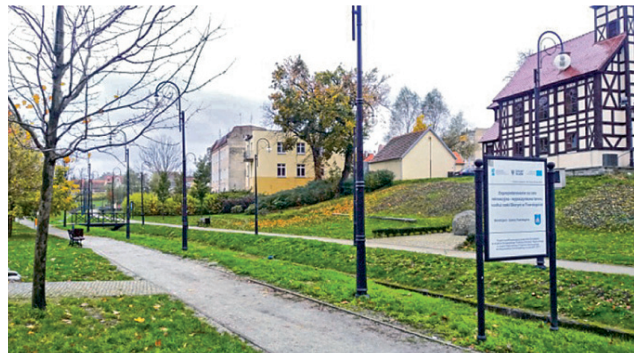

Rys. 11. Deptak wzdłuż rzeki Skoryni

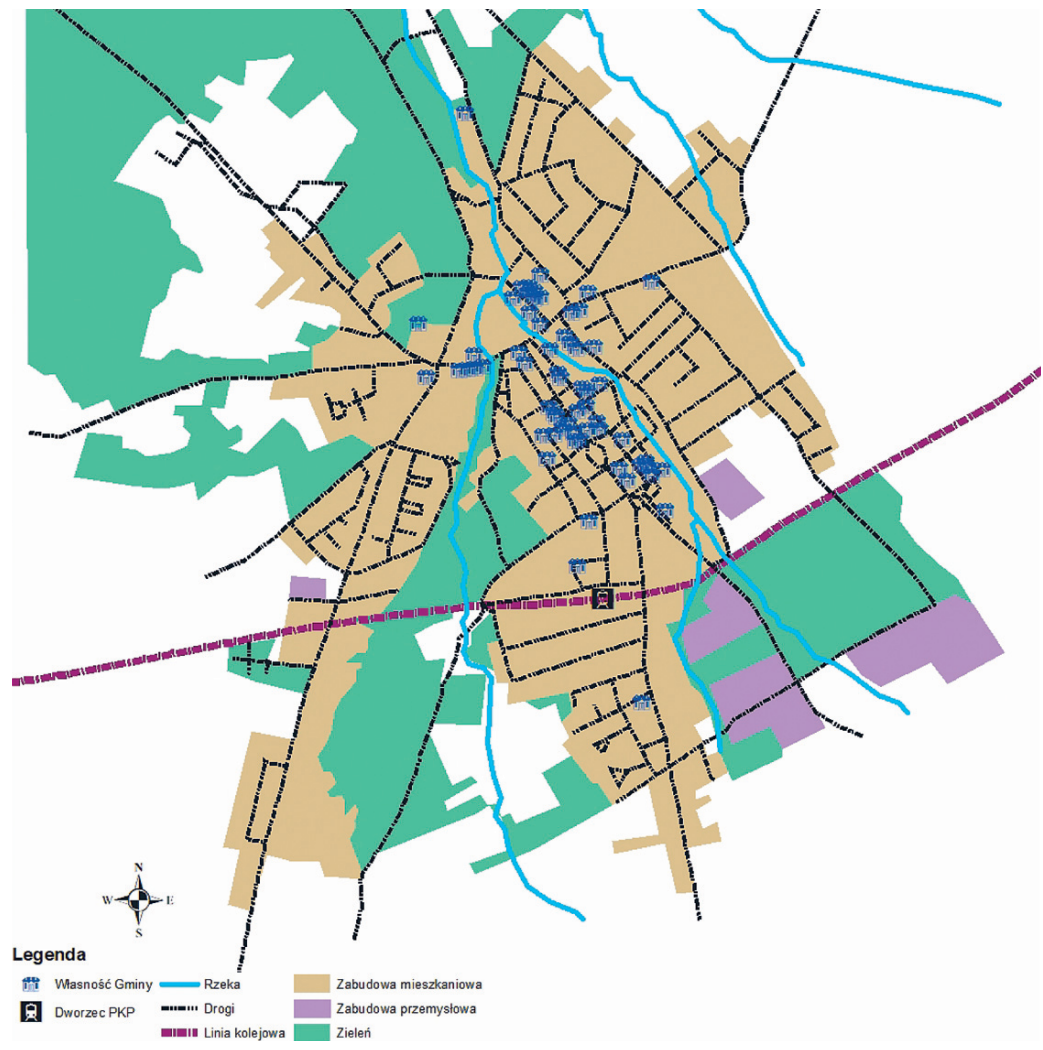

Rys. 12. Struktura funkcjonalno-przestrzenna miasta Twardogóra

Twardogóra to miasto posiadające największą bazę mieszkań komunalnych wśród wszystkich 12 małych miast do 10.000 mieszkańców biorących udział w badaniu, tj. 62 budynki w 100\% własności Gminy, a to daje 494 lokale. Zabudowa komunalna znajduje się głównie w centrum miasta, z wyjątkiem 2 obiektów oddalonych ponad $1 \mathrm{~km}$ od rynku (Rys. 12). Większość budynków wpisana jest do rejestru zabytków, niektóre z nich mają odnowioną elewację i uporządkowane, choć niewielkie podwórka. Jeden z 62 budynków ma dostęp do placu zabaw i prawie połowa nie ma przydomowej zieleni lub ogródka. Przestrzeń przed budynkiem rzędu kilkudziesięciu metrów kwadratowych, w większości jest przeznaczona na parking, a im bliżej centrum, tym jest ona coraz mniejsza, co utrudnia zapewnienie mieszkańcom komfortu korzystania z podwórka (Rys. 17). 
Tabela 3. Własności miasta Twardogóra - zabudowa mieszkaniowa wielorodzinna

\begin{tabular}{|c|c|c|c|c|c|}
\hline $\begin{array}{l}\text { adres } \\
\text { nieruchomości }\end{array}$ & zabytek & $\begin{array}{c}\text { droga } \\
\text { dojazdowa }\end{array}$ & $\begin{array}{l}\text { odległość } \\
\text { do centrum }\end{array}$ & $\begin{array}{c}\text { stan } \\
\text { techniczny }\end{array}$ & $\begin{array}{c}\text { sposób zagospodaro- } \\
\text { wania i wykorzystania } \\
\text { podwórka }\end{array}$ \\
\hline $\begin{array}{l}1 \text { pl. Kolejowy 1, } \\
\text { ul. Piastów } 17\end{array}$ & tak & asfalt & $500 \mathrm{~m}$ & bardzo dobry & zły \\
\hline 2 pl. Piastów 13, 14, 21 & nie & asfalt & $250 \mathrm{~m}$ & dobry & zły \\
\hline 3 ul. 1-go Maja 1, 3 & tak & asfalt & $350 \mathrm{~m}$ & bardzo dobry & zły \\
\hline 4 ul. Aleje 6 & nie & asfalt & $600 \mathrm{~m}$ & dobry & dobry \\
\hline 5 ul. Bydgoska 5, 7, 7a, 11 & tak & asfalt & $400 \mathrm{~m}$ & dobry & zły \\
\hline 6 ul. Dąbrowskiego 1, 3 & nie & kostka & $100 \mathrm{~m}$ & dobry & zły \\
\hline 7 ul. Długa 9, 11, 13 & tak & asfalt & $400 \mathrm{~m}$ & dobry & bardzo dobry \\
\hline 8 ul. Długa 32 & tak & asfalt & $400 \mathrm{~m}$ & dobry & dobry \\
\hline 9 ul. Gdańska 5 & tak & asfalt & $500 \mathrm{~m}$ & dobry & bardzo dobry \\
\hline 10 ul. Krótka 1 & tak & kostka & $250 \mathrm{~m}$ & bardzo dobry & zły \\
\hline 11 ul. Krótka 9 & tak & kostka & $100 \mathrm{~m}$ & bardzo dobry & zły \\
\hline 12 ul. Krzywoustego 1a, 3 & nie & kostka & $50 \mathrm{~m}$ & dobry & zły \\
\hline 13 ul. Krzywoustego 10 & nie & kostka & $150 \mathrm{~m}$ & dobry & dobry \\
\hline 14 ul. Lipowa 9 & tak & asfalt & $500 \mathrm{~m}$ & dobry & zły \\
\hline 15 ul. Lipowa 37 & nie & asfalt & $1100 \mathrm{~m}$ & dobry & dobry \\
\hline 16 ul. Młyńska 1 & tak & asfalt & $350 \mathrm{~m}$ & bardzo dobry & dobry \\
\hline $\begin{array}{l}17 \begin{array}{l}\text { ul. Młyńska 4, 4a, 6, } \\
\text { 6a, 8, 8a 9 }\end{array} \\
\end{array}$ & tak & asfalt & $350 \mathrm{~m}$ & dobry & dobry \\
\hline 18 ul. Ogrodowa 2 & nie & asfalt & $350 \mathrm{~m}$ & dobry & dobry \\
\hline 19 ul. Oleśnicka 8 & tak & asfalt & $1100 \mathrm{~m}$ & dobry & dobry \\
\hline 20 ul. Poznańska 1a & nie & asfalt & $600 \mathrm{~m}$ & bardzo dobry & bardzo dobry \\
\hline 21 ul. Ratuszowa 1c, 4 & tak & asfalt & $200 \mathrm{~m}$ & dobry & zły \\
\hline 22 ul. Ratuszowa 9, 39a & tak & asfalt & $200 \mathrm{~m}$ & dobry & zły \\
\hline 23 ul. Ratuszowa 43 & tak & asfalt & $200 \mathrm{~m}$ & bardzo dobry & zły \\
\hline 24 ul. Rynek 2, 3, 6, 17, 20 & tak & kostka & $100 \mathrm{~m}$ & dobry & zły \\
\hline 25 ul. Sienkiewicza 2 & tak & kostka & $400 \mathrm{~m}$ & dobry & zły \\
\hline 26 ul. Sienkiewicza 5 & nie & kostka & $400 \mathrm{~m}$ & dobry & dobry \\
\hline 27 ul. Sienkiewicza 8 & tak & kostka & $450 \mathrm{~m}$ & dobry & zły \\
\hline 28 ul. Sosnowa $3 \mathrm{a}$ & nie & asfalt & $600 \mathrm{~m}$ & zły & zły \\
\hline $\begin{array}{l}29 \begin{array}{l}\text { ul. Wielkopolska } 19, \\
20,22,48\end{array} \\
\end{array}$ & tak & asfalt & $500 \mathrm{~m}$ & dobry & dobry \\
\hline 30 ul. Wielkopolska 7 & tak & asfalt & $300 \mathrm{~m}$ & zły & zły \\
\hline $\begin{array}{ll}31 & \text { ul. Wrocławska 11, } \\
13,15,17\end{array}$ & tak & asfalt & $350 \mathrm{~m}$ & dobry & dobry \\
\hline 32 ul. Wrocławska 14 & tak & asfalt & $400 \mathrm{~m}$ & dobry & zły \\
\hline 33 ul. Wrocławska 32 & tak & asfalt & $550 \mathrm{~m}$ & dobry & bardzo dobry \\
\hline
\end{tabular}


Na rycinach poniżej i w tabeli powyżej można zaobserwować efekt szczegółowej oceny budynków mieszkalnych wielorodzinnych i zagospodarowania terenu wokół nieruchomości. Ze względu na obszerne opracowanie, po wykonanej analizie, obiekty, które prezentowały takie same cechy pogrupowano i zestawiono w jednym wierszu. (Stąd kilka adresów w niektórych wierszach.)

Zabudowa mieszkaniowa w sąsiedztwie rynku to w większości 2-kondygnacyjne kamienice (Rys. 13), dalej od centrum zmienia się w 2-, 3- lub 1-kondygnacyjne bloki lub budynki wielorodzinne z lat 60.-80. XX wieku (Rys. 15). W niektórych z nich oprócz ogrodu od frontu budynku (Rys. 15), można znaleźć sad na zapleczu (Rys. 16). Często pogrupowane są w kilka obiektów, połączone jednym podwórkiem, tj. w przypadku ul. Wrocławskiej 13, 15 (Rys. 18).

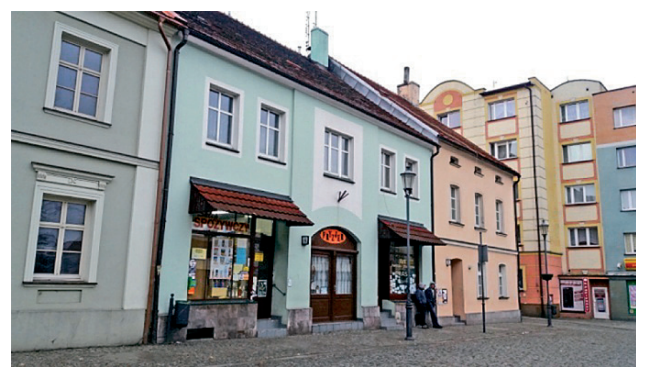

Rys. 13. ul. Rynek 6, front budynku

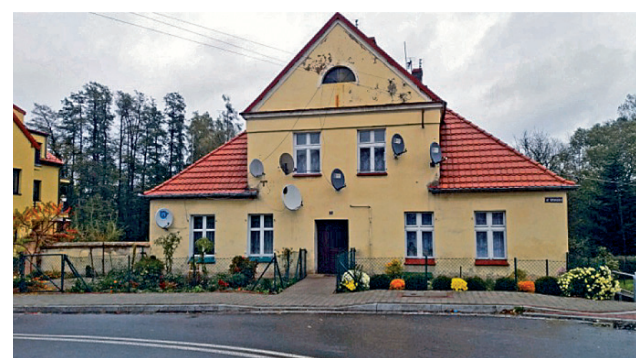

Rys. 15. ul. Gdańska 5, front budynku

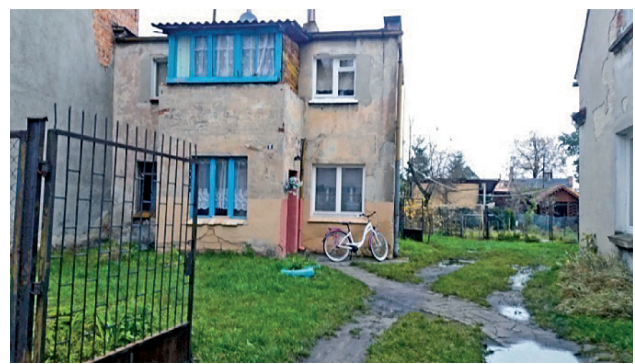

Rys. 17. ul. Młyńska 8, front budynku

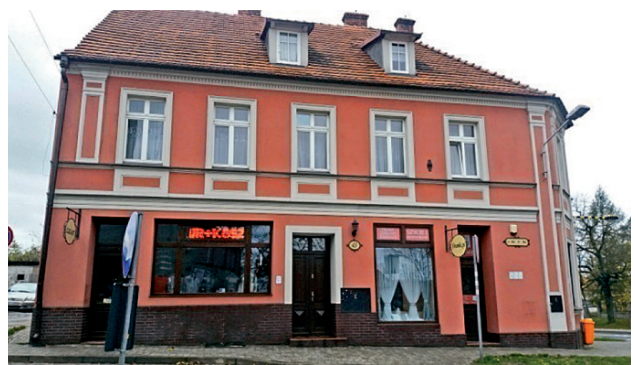

Rys. 14. ul. Ratuszowa 43, front budynku

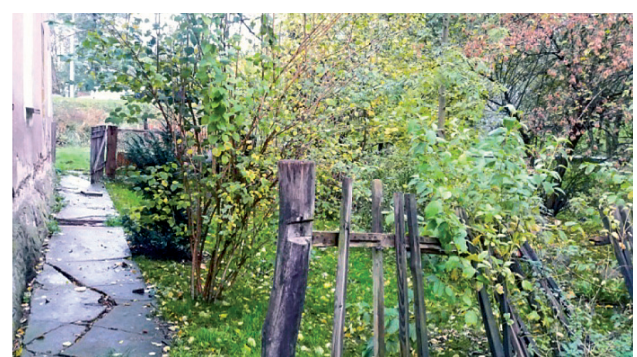

Rys. 16. ul. Gdańska 5, podwórko

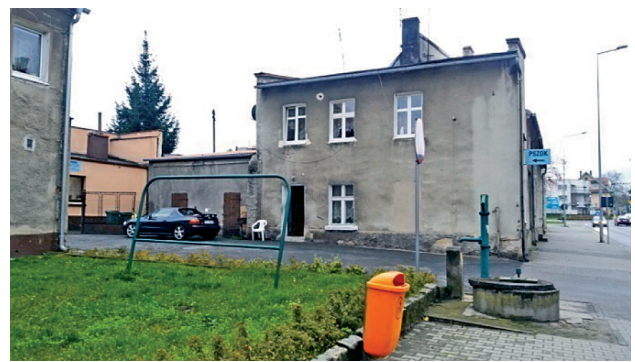

Rys. 18. ul. Wrocławska 13, 15, front budynków

\section{Podsumowanie}

W swojej analizie Autorka skupiła się na ocenie sposobu zagospodarowania terenów komunalnej zabudowy mieszkaniowej oraz stanu technicznego budynków. Szczegółowa 
inwentaryzacja mienia komunalnego jest jednym z etapów projektu badawczego, w którym Autorka podejmuje próbę stworzenia optymalnego modelu zagospodarowania komunalnych terenów mieszkaniowych w małych miastach do 10.000 mieszkańców na przykładzie województwa dolnośląskiego. W zaprezentowanych dwóch miastach mamy do czynienia z polityką mieszkaniową, w której władze samorządowe starają się utrzymać ilościowy zasób mieszkaniowy. Z przeprowadzonej inwentaryzacji terenu wynika, że bogaty ilościowo zasób mieszkaniowy, prezentuje niski poziom standardu zabudowy komunalnej: brak ocieplenia, stary dach, okna i drzwi oraz brak zagospodarowania terenów wokół: na wolnych przestrzeniach przed budynkami nielegalne parkingi, nieuporządkowana zieleń. Część budynków tworzy kompleksy zabudowy na wspólnych działkach budowlanych, co w przypadku chęci mieszkańców i władz może ułatwić zagospodarowanie i wytworzenie miejsc integracji społecznej. Dobrym elementem partycypacji społecznej w tym przypadku mogłaby być wspólna realizacja podwórek, która poprawiłaby poczucie własności i tożsamości mieszkańców z własną przestrzenią.

\section{Literatura}

[1] Ogrodowczyk A. Polityka przestrzenna a rozwój budownictwa mieszkaniowego po 1990 roku na przykladzie małych miast w województwie tódzkim. Acta Universitatis Lodziensis Folia Geographica Socio-Oeconomica, 11/2001, Łódź 2011, s. 167.

[2] Ustawa z dnia 21 czerwca $2001 \mathrm{r}$. o ochronie praw lokatorów, mieszkaniowym zasobie gminy i o zmianie Kodeksu cywilnego, Dz. U. z 2016 r. poz. 1610 z późn. zm.

[3] Muczyński A. Gospodarowanie gminnymi zasobami lokalowymi z perspektywy polityki mieszkaniowej, Studia i Materiały Towarzystwa Naukowego Nieruchomości, 19(2) (2011) 8.

[4] Źróbek-Różańska A. Uwarunkowania prawne gospodarki nieruchomościami w gminie w aspekcie ksztaltowania jej rozwoju, Studia i Materiały Towarzystwa Naukowego Nieruchomości, 19(2) (2011) 41-42.

[5] Ustawa z dnia 27 marca 2003 r. o planowaniu i zagospodarowaniu przestrzennym, Dz. U. z 2017 r. poz. 1073 z późn. zm.

[6] Uchwała nr XXXIV.220.2013 Rady Miejskiej w Chocianowie z dnia 23 maja 2013 r. w sprawie uchwalenia studium uwarunkowań i kierunków zagospodarowania przestrzennego gminy Chocianów.

[7] Uchwała nr XII/66/07 Rady Miejskiej w Twardogórze z dnia 26 października 2007 r. w sprawie uchwalenia zmiany studium uwarunkowań i kierunków zagospodarowania przestrzennego Miasta i Gminy Twardogóra.

[8] Prus B. Sytuacja planistyczna w Polsce - studium porównawcze, Infrastruktura i ekologia terenów wiejskich, nr 2/II/2012, Kraków 2012.

[9] Stettner M. Rewitalizacja a obraz miasta czyli znaczenie procesów odnowy przestrzeni małych miasta dla społeczności lokalnej, [w:] Innowacyjne rozwiązania rewitalizacji terenów zdegradowanych Tom 7. (ed. Skowronek J.). Instytut Ekologii Terenów Uprzemysłowionych, Katowice 2015. 


\title{
Assessment of the standard of municipal housing in a small town on the example of Twardogóra and Chocianów
}

\author{
Milena Stettner \\ Department of Urban Planning, Faculty of Architecture, Wroctaw University of Science and Technology, \\ e-mail:milena.stettner@pwr.edu.pl
}

\begin{abstract}
The condition of multi-family housing development depends on the town's policy regarding the shaping of the communal resources. This is noticeable compared to the availability and technical standards of buildings. The author analyzes the directions of spatial development of the municipality and compares it with detailed evaluation of multi-family housing development in selected small towns up to 10.000 inhabitants: Chocianów and Twardogóra (located in the Lower Silesian Voivodship) - towns presenting the idea of maintaining large housing stock and thus controlling the development of housing. The article presents one of the stages of the research project - a detailed inventory of municipal property and analysis of planning documents in two small towns with a similar housing policy, population size, without the influence of the metropolitan city - which aims to create an optimal model of municipal housing development in the downtown of small towns up to 10,000 inhabitants in the Lower Silesian Voivodship.
\end{abstract}

Keywords: housing policy, quality of life, housing conditions, resource municipal. 